First Peoples Child \& Family Review

An Interdisciplinary Journal Honouring the Voices, Perspectives, and Knowledges of First Peoples through Research, Critical Analyses, Stories, Standpoints and Media Reviews

\title{
Re-Conceptualizing Research: An Indigenous Perspective
}

\section{Naadli Todd Ormiston}

Volume 5, Number 1, 2010

URI: https://id.erudit.org/iderudit/1069061ar

DOI: https://doi.org/10.7202/1069061ar

See table of contents

Publisher(s)

First Nations Child and Family Caring Society of Canada

ISSN

1708-489X (print)

2293-6610 (digital)

Explore this journal

Cite this article

Ormiston, N. (2010). Re-Conceptualizing Research: An Indigenous Perspective. First Peoples Child \& Family Review, 5(1), 50-56.

https://doi.org/10.7202/1069061ar

\section{Article abstract}

This paper validates the differing in which Indigenous people are re-conceptualizing research as a form of decolonization, regeneration of cultures and communities, and ultimately self- determination. Indigenous people are taking control of their own destinies by providing needed solutions from within, as individuals, communities and Nations. This paper provides suggestions to indigenize the research process. This paper also includes principles provided by Irabinna (Dr. Lester Rigney) of Australia, the need to historicize, politicize, strategize and actualize our beings and our futures. Ultimately, the inspiration to write this paper comes from my Tlingit ancestors.
This document is protected by copyright law. Use of the services of Érudit (including reproduction) is subject to its terms and conditions, which can be viewed online.

https://apropos.erudit.org/en/users/policy-on-use/ 


\title{
Re-Conceptualizing Research: An Indigenous Perspective
}

\author{
Naadli Todd Ormiston ${ }^{a}$
}

\begin{abstract}
a (Wolf Clan) is Northern Tutchone \& Tlingit. He holds a Bachelor of Social Work Degree and a Masters in Public Administration. Currently, Todd works at the University of Victoria as a sessional instructor. In addition, he is currently the program leader at Camosun College in the Indigenous Studies Diploma Program. Todd's lengthy career as a social services worker included working with youth involved in the criminal justice system. His teaching and research interests have a strong focus on Policy Issues \& Indigenous Peoples in Social Work.
\end{abstract}

\section{Introduction}

From the vantage point of the colonized, a position from which I write, and choose to privilege, the term 'research' is inextricably linked to European imperialism and colonialism. The word 'research' is probably one of the dirtiest words in the indigenous world's vocabulary. When mentioned in many indigenous contexts, it stirs up silence, it conjures up bad memories, it raises a smile that is knowing and distrustful. (Smith, 1999, p.1).

Historically, research undertaken since colonization on Indigenous ${ }^{1}$ lands and on Indigenous people has resulted in the phenomenon that Indigenous people are the most researched people on earth. Until recently, most of this research has been conducted on Indigenous people, culture and lands without the permission, consultation, or involvement of the people being researched. In its earliest form, this resulted in the removal of Indigenous people from their homelands, the suppression of their nationhood, the replacement of their governments, and

\footnotetext{
1 The terms Indigenous, Aboriginal and Indian are used interchangeably in this article.
}

Questions or correspondence concerning this article may be addressed to:

E-mail: toddo@shaw.ca

\begin{abstract}
This paper validates the differing ways in which Indigenous people are re-conceptualizing research as a form of decolonization, regeneration of cultures and communities, and ultimately selfdetermination. Indigenous people are taking control of their own destinies by providing needed solutions from within, as individuals, communities and Nations. This paper provides suggestions to Indigenize the research process. This paper also includes principles provided by Irabinna (Dr. Lester Rigney) of Australia, the need to historicize, politicize, strategize and actualize our beings and our futures. Ultimately, the inspiration to write this paper comes from my Tlingit ancestors.
\end{abstract}

the destruction of their identities and cultures (Battiste, 2000). Today it continues through the eradication/marginalization of Indigenous people's right to self determination, through the development of inappropriate or misguided policies, and through programs designed to assimilate - designed to solve "the Indian problem." The general belief persists that problems within Indigenous communities need to be corrected by outside interests.

Despite the pervasiveness of this paradigm, Indigenous people are finding their voices and continuing to resist this oppression. In many ways, this article validates the differing ways in which Indigenous people are recognizing, re-claiming and re-defining their worldviews as part of the process towards decolonization, restoration of our cultures and communities and, ultimately self-determination. Indigenous people continue to take control of their own destinies by providing needed solutions from within, as individuals, communities and Nations. This article acknowledges the diversity of cultures, traditions, and differing, yet related, ways of being, seeing, knowing and doing of Indigenous people worldwide. It provides suggestions to Indigenize the research process. This article also includes principles provided by Irabinna (Dr. Lester Rigney) of Australia to historicize, politicize and strategize 
our beings and our futures, and also explores the concepts of actualizing, decolonizing and re-conceptualizing research. Ultimately, the inspiration to write this article comes from my Tlingit ancestors.

\section{What is Colonialism and Euro-Centrism, and How Have they Oppressed Indigenous People? (Historicize)}

Discussion of the need to reconceptualize the research process means we must challenge constructs such as colonialism and Euro-centrism. Colonialism, in its most traditional sense, involved the "gaining of control over particular geographical areas and is usually associated with the exploitation of various areas in the world by European or American powers" (Carnoy, 1974, p. 21). Perley (1993) has identified four basic components of colonialism: 1) the forced, involuntary entry of the colonized group into the dominant society; 2 ) the colonizing power of adopting policies that suppress, transform, or destroy Native values, orientations and ways of life; 3 ) manipulation and management of the colonized by agents of the colonizing group; and 4) the domination, exploitation and oppression justified by an ideology of racism, which defines the colonized group as inferior (p. 119). Indigenous people worldwide have continuously been subjugated to invasion, whether violent or under the auspices of "civilizing," "assimilating" or "integrating" in order to expropriate lands, traditions and culture. In Canada, the Indian Act ${ }^{2}$, residential schools ${ }^{3}$, and the "60s scoop" (provincial apprehension and fostering/adopting out of Indian children to non native homes) are some of the direct results of colonization. The justice system, through the incarceration of our people continues to perpetuate colonialism. The situation is eerily similar across the Americas. In Hawai i, foreign (American) laws and policies suppressed the original peoples. Trask (1999) stated, "From the banning of our language and the theft of our sovereignty to forcible territorial incorporation in 1959 as a state of the United States, we have lived as a subordinated Native people in our ancestral home" (p. 18). Battiste suggested that Euro-centrism is manifested as the "dominant consciousness and order of contemporary life. Universality replaces diversity. The dominant values become the norm and the minority becomes trivialized and thus devalued or even ignored" (classroom lecture, 2001). Academic

\footnotetext{
2 This Act singles out native peoples, largely on the basis of race, removes much of their traditional land and property (and isolating people from mainstream society). Many aspects of their lives are placed in the control of the state.

3 Church led schools where over 100,000 native children were mandated to assimilate into mainstream society through 1) moral training 2) domestic/ agricultural training and 3 ) a small form of formal education.
}

policy and curricula privilege Euro-centric perspectives and values.

Little Bear (2000), spoke to these similarities worldwide when he emphasizes that one of the problems with colonialism is "that it tries to maintain a singular social order by means of force and law, suppressing the diversity of human worldviews" (p. 84). Within time, many Indigenous people have learned to embrace this "singular social order" as common sense wisdom, which, in fact, works against their interests and serves those of the powerful- a term described by Antonio Gramsci as 'hegemony'.

Hegemony has affected me greatly through education. I have often come to believe what I was taught, or what I read to be the truth. I was a part of the sixties scoop and, as such, I was fostered out to four non-native homes before being adopted by the last home I was placed in and taught to live my life based on catholic values. My own experience illustrates that due to the pervasiveness of Euro-centric knowledge through colonization, Indigenous people today often do not have many valid methodologies at their disposal that embrace an Indigenous worldview in the search for truth (Battiste, 2000). This is changing today as many of our people are fighting the struggle to free themselves of oppression. Nonetheless, the "truth" that others have conveniently defined (and search for) often results in traditions and aspects of our culture being appropriated from our communities that furthers the mistrust with non-Indigenous peoples. In his article "Putting Words into Action: Negotiating Collaborative Research in Gitxaala," Menzies (2004) illustrated an experience common to many Indigenous people and their cultures when he spoke of research that was supposed to remain with/ensure the survival of the Gitxaala people:

At the heart of the account was a government sponsored research project into the health and location of abalone conducted in the recent past. The government researchers explained that their project would benefit the local community. This would be accomplished by collecting location and population data that would make the job of protecting the abalone grounds from over harvesting and poaching more effective. After some consideration, community members agreed and a number of surveys were completed. Following the departure of the researchers, a fleet of commercial dive boats turned up on the abalone grounds that had been described to the researchers. The end result was the complete degradation of the local grounds and ultimately a complete closure of commercial abalone fishing on the coast. The community members who had participated in the study felt betrayed by the process (p. 22).

4 Cultural hegemony is the philosophic and sociological theory that a diverse culture or population can be ruled by one social class and the ideologies of that social class. 
Tlingit teachings suggest that in order to have yan gaa duuneek (dignity), individuals must not aspire to know everything. If people try to explain everything or choose to leave nothing unexplored in the world, they will bring tragedy upon themselves, for they are then aspiring to be gods and not humans (Beck \& Walters, 1977). Most Indigenous people do not seek out scientific ways of controlling/predicting behaviour or what will occur in the future. Within Indigenous worldviews is the spiritual belief, which acknowledges how powerless humans really are in comparison to the vast and incomprehensible forces of the universe (Ross, 1996, p. 69).

Whereas the Indigenous perspective emphasizes the interconnectedness of the spiritual, physical, emotional, and intellectual aspects of being, the Euro-centric worldview perceives these as disparate and fragmented. A prime example of this can be found in government research, which is geared mainly toward its own needs while ignoring the connectedness to community well being. Statistics Canada and the Bureau of Indian Affairs in the United States are examples of this perspective - spending millions of dollars annually gathering data on social/economic situations in our communities for their purposes with little return to the community. Years ago, I gathered information on drinking patterns among Aboriginal teens in Whitehorse, Yukon for the territorial government. Although indicators were gathered that identified clear socialeconomic patterns that could have resulted in meaningful change, the final report failed to mention any strategies for healing that could or should be enacted for the wellbeing of our people. The statistics produced in the final report perpetuated the stereotype that Aboriginal teens consume the most alcohol of any racial group in Canada. Often, outsider "research" fails to focus on meaningful solutions that would directly result in improvement of conditions. Far too often, there is no planning or consultation between the researchers, institutions, or the local community and the service providers in terms of what type of research and services might be needed (Wax, 1991). The result has been that Indians are taught to view themselves as the lowest group on the scale of social indicators.

In other instances, governments merely give the appearance of superficial interest in exploring significant Indigenous issues. The Report of the Royal Commission on Aboriginal Peoples (Indian and Native Affairs Canada, 1996) is a prime example. It was supposed to set the stage for a post-colonial agenda for Aboriginal people in Canada. It was the largest research project ever undertaken in Canada, with a report consisting of more than 4200 pages. Over 400 recommendations were made that were designed to create a new relationship between the state and Indigenous people. Apparent throughout the report's findings was the fact that "the painful legacy of colonial history bears heavily upon Aboriginal people in the form of cultural stress" (Battiste, 2000, p. 8,). What can be done when research reports that articulate injustices and make recommendations for change remain dormant? It is essential that we not ignore or dismiss the real agenda imposed from outside. We have an obligation to each other to fight for change through the sharing of information and by bringing these issues on a collective level to the forefront within our own Nations and Western agendas. It is as much about standing up for and re-claiming ourselves, as it is about challenging colonialism and Euro-centric thought in order to create a future for our next generations. Ultimately, by honoring the Indigenous worldview with the respect and integrity it so richly deserves, we will reawaken the spirit of the original peoples of this land.

\section{The Importance of Oral Traditions (Politicize)}

For the Tlingit, as for other Indigenous cultures, it is clear that Indigenous people need to be given the room and freedom to reclaim and recover from colonial ideologies, including the belief that non-Aboriginal researchers can adequately capture and portray a culture different from their own. There needs to be some understanding by all that "oral" traditions do not need to be saved and preserved through written records for Indigenous peoples' own good. We have survived and flourished historically without the printed page (Callison, 1995).

Our teachings are centered on oral traditions; incorporated into the voice of self is the voice of the "cultural collective." Cecilia Kunz, an elder, says that in the Tlingit world, everything — animals, the land, the sky, the rain — is alive. This belief and understanding about the interconnectedness between humans and the natural world become the central idea of our stories (C. Kunz, personal communication, July 12, 2007). Oral traditions encompass abstract concepts such as spirituality and philosophical beliefs that guide and shape Tlingit ways of being. Oral histories offer future generations the path of knowledge that informs their heritage, their ways of knowing and being. They involve "informal story-telling, formal narrative, political discourse, names, songs and prayer" (Battiste \& Henderson, 2000, p. 9). Oral histories are personal; oral histories are rich and multidimensional. They incorporate notions of a world that is ever-changing, one that includes different levels of existence. They encourage abstract thinking, creativity and imagination, which are building blocks for intelligence. The view here is that it is neither beneficial, nor desirable to impose an alien, colonial reality onto one which is Indigenous. Why is it, then, that Western researchers often 
claim their methodology as legitimate and the "true" form of acquiring knowledge? What is clear through Western research is that often all other forms of epistemology are dismissed or minimized (Trigger \& Williams, 1997).

\section{Decolonization as a Step Towards Indigenizing the Research Process}

\author{
... Indigenous people now want research and its designs \\ to contribute to the self determination and liberation \\ struggles as defined and controlled by their communities. \\ To do this, Indigenous people themselves must analyze \\ and critique epistemologies that are commonplace in \\ higher education" (Rigney, 1999, pp. 109-110).
}

Any step towards decolonization involves examining what "truth" is. This requires re-examining histories and understanding them from differing perspectives. One of the most profound beliefs in Tlingit philosophy is that there is no such thing as one reality, let alone an "absolute truth." This notion is not easy for many non-Indigenous people to accept because it involves a fundamental spiritual and experiential shift in their approach to knowledge. However, those of us who are Indigenous need to locate and re-discover our history as it relates to our Nations. We need to recover/re-claim our culture, ceremonies, language, values and identity whenever possible. Decolonization is about privileging, understanding and sharing our concerns and worldviews. We must then come to know and understand theory and research from our own perspectives, for our own purposes (Battiste, 2000). Through understanding, we create and utilize knowledge as a form of resistance to Euro-centrism. Although change is slow, the need to tell our stories "remains the powerful imperative of a powerful form of resistance" (Smith, 1999, p. 35).

\section{Towards an Indigenous Way of Conducting Research (Strategize)}

It should be understood that research in itself is not inherently 'bad,' it is generally the 'people factor'- that is people's intentions, motivations and interests which shape a particular research project. Our task as Indigenous people, is not only to claw back the appearance of control by renaming research as indigenous research; we must also claw back ownership of the control over the intentions, purposes, motivations and interests of the total research process (G. H. Smith, personal communication, 2003).

As more of our people reclaim our traditional ways of knowing, being, seeing and doing, the face of research will change. Indigenous research involves utilizing core elements of Indigenous worldviews, which are distinct amongst particular locations and groups of people. Today, the respect for Indigenous knowledge has to begin with our people providing the standards and the protections that accompany the "centering" of Indigenous knowledge (Battiste, 2000). In her article "Heart Knowledge, Blood Memory, and the Voice of the Land: Implications of Research among Hawaiian Elders," Holmes (2000) spoke to three realities of the Kupana (elders) and their relationship to centering Indigenous knowledge. It was through the Kupana that [Indigenous] knowledge lodges in the heart of the listener, referred to as "heart knowledge." Heart knowledge links knowledge to connection with identity, values and relationships. Secondly, "blood memory" speaks to the importance of blood, family (genealogy) and the view that experience is essential to knowledge. This is powerful for me because I seek knowledge from my elders partly due to the experiences I have not yet had; they are the living memory based on being, seeing and doing. Thirdly, the elders in Hawai i speak to the "voices of the land." We have many teachings that flow from the land (mother earth) and we need to return to those teachings, as they are a form of our traditional values, our ways of knowing. Holmes (2000) referred to these three realities as constituting an 'ancestry of experience that "shapes, dreams, desires, intentions and purposeful activities" (p. 47). Indeed, we need to look to the past in order to understand who we are and to know where we are going.

Vital to Indigenous research is that it benefits our people, our communities, and our Nations. All researchers working in an Indigenous context have an ethical responsibility toward the people, their cultures, and the environment. As part of this process, it is essential to include those who have been marginalized through colonization, particularly the voices of our young people, women, and elders.

An important aspect of any research in an Indigenous context is that researchers should be sensitive to the economic, social, spiritual, and general welfare of the individuals and cultures on and among whom they do research. Too many times in the past, researchers have used their role of authority or position of power to oppress those they research, and/or they have disregarded the community's cultural/traditional/ shared knowledge. They provide their own (often false) interpretations of what people have shared. When working on my Master's thesis titled Aboriginal Child and Family Services: A First Nations Analysis of Delegated Services in BC (Ormiston, 2002), I knew the importance of asking Indigenous social workers open-ended questions that would allow them, as participants, the opportunity to expand and speak their minds freely. They began to articulate the problems within the broad policy they must adhere to, and they offered solutions to alleviate or change their situations. I knew I 
had the responsibility to include the people I interviewed when analyzing the data (and what was to be considered public information). As a result, the 12 recommendations I highlighted for emerging Indigenous social work students in post secondary institutions came directly from the participants interviewed. They carried the knowledge that had to be validated. As Taiaiake Alfred" stated: "Indigenous people/ communities who are happy, successful, reconnected or have recovered have done so outside of the frameworks that have been built to address those problems (such as external governments, the Courts etc.). It has been through a process of reconnecting with Indigenous people who hold that knowledge and the values that leads to us providing our own solutions" (G. T. Alfred, personal communication, March 22, 2006). Alfred provides a compelling argument that you cannot change a system from within. He contended that you have to confront the system from outside with a different moral base "or else the system will crush you or entice you to be a servant in that system." Who better knows the issues and can provide solutions to those issues than our people?

\section{The Need to Develop Principles for Conducting Research in an Indigenous Context (Actualize)}

Many communities/institutions and Nations are taking the proactive step of developing guidelines to determine what research may be conducted on Indigenous people/lands. Although these vary among groups and localities, the ultimate goal is for researchers to respect the people and cultures being studied. The Mi'kmaw (First People from what is known as Nova Scotia, Canada) have developed their Nation's Principles and Protocols with the clear understanding that "Mi' kmaw people are the guardians and interpreters of their culture and knowledge system- past, present and future" (Cape Breton University, 2010). These principles were designed to ensure that the integrity and cultural knowledge of the Mi'kmaw people would be preserved. To this end, a Mi'kmaw Ethics watch committee has been formed under the Grand Council, to review any research into collective knowledge, culture, arts and spirituality.

AIATSIS (The Australian Institute of Aboriginal and Torres Strait Islander Studies in Australia; 2000) undertakes and encourages scholarly, ethical community-based research, has the world's largest print collection on Indigenous Studies material, and has its own publishing house (http:/ /www.aiatsis. govau/corporate/about.html). Its activities affirm and raise awareness among all Australians, and people of other countries,

5 Taiaiake is a Professor of Indigenous Governance at the University of Victoria and is known for his leadership and research in the fields of Indigenous governance, philosophy and history. of the richness and diversity of Australian Indigenous cultures and histories. The Institute has also developed Guidelines for Ethical Research in Indigenous Studies. These involve 11 principles under three headings to which researchers must adhere when conducting research in an Indigenous context. These headings are: a) Consultation, Negotiation and Mutual Understanding; b) Respect, Recognition and Involvement; and c) Benefits, Outcomes and Agreement (AIATSIS, 2000). Within this document it is clearly articulated that:

Research concerning Indigenous Peoples should be carried out with appropriate consultation about the aims and objectives and meaningful negotiation of processes, outcomes and involvement. Relevant communities and individuals should be involved at all stages of the research process, from formulating projects and methods to determining research outcomes and interpreting results. (AIATSIS 2000)

Similarly, the University of Victoria (2003) in Canada has developed Protocols \& Principles for Conducting Research in an Indigenous Context. This policy works in conjunction with the University's Human Ethics in Research Sub-committee. However, in order for any research to proceed, final approval must be given by the Indigenous Research Sub-committee, which is made up of Indigenous members. These protocols were developed so that any research on or involving Indigenous people that is sponsored by the Faculty of Human and Social development will give "appropriate respect ... to the cultures, languages, knowledge and values of Indigenous peoples, and to the standards used by Indigenous peoples to legitimate knowledge." Community protocols developed by and for individual Nations can work in tandem with University protocols to ensure research is conducted in a respectful, responsible manner. These initiatives are essential to de-colonizing the research process and validating Indigenous ways of knowing, being, seeing and doing.

\section{Re-Conceptualizing Research: An Indigenous Perspective}

In essence, a re-conceptualization of the research process from an Indigenous perspective would include the following:

- Less emphasis on the individualistic notion of a "principal researcher" defining a "research question" and more emphasis on community definition/involvement in terms of what needs to be researched (what is transformative about the research for Indigenous people/communities?), and on how this research will be conducted at all stages;

- Inclusion of Indigenous worldviews through methodologies based on the distinctiveness of each "nation"; 
- Standards and Principles for their communities/ organizations/ institutions that apply to ALL people conducting research in an Indigenous context;

- Recognition that communities OWN the research conducted. Copyright is to be retained by the community;

- Commitment to Indigenous People conducting their own research whenever possible. Because social science methodology can never truly be "value free," questions arise as to whom Indigenous people are being compared and whether the researchers know the culture or history of Indigenous people (Gilchrest 1997);

- Social movement strategies that ensure responsibility, where the results of research always explore strategies for healing and community development;

- Researchers bringing a "thorough background on the history of colonialism and Euro-centrism and a broadbased knowledge of Indigenous history and culture when engaging in research in our communities" (Gilchrest, 1997);

- Proficiency/ fluency in Aboriginal languages (Battiste \& Henderson, 2000);

- Awareness the effects (benefits and risks) the research may have on individuals, communities and Nations;

- Understanding that the elders have wisdom gained through experience, and that they know when it is time for the teachings to be shared;

- Always remembering our values as Tlingit people when conducting research:

- Respect for self and others

- Remember our traditions, our families, sharing, loyalty, pride

- Responsibility to future generations

- Many truths

- Care of subsistence areas, care of property

- Reverence. We have a great word in or culture: haa shageinyaa. This is the great spirit above us. (Soboleff, P., personal communication 2003)

As a Tlingit person, I carry the responsibility to conduct research and develop methodologies with the above elements in mind. When it comes to developing an Indigenous academic site (or conducting any research in higher education), it is imperative that Indigenous knowledge be centered. The same assertion for theory can be made (as it is socially constructed). Although this article does not focus on the need to reconceptualize theory, I believe we need to challenge both research and theory within higher education to ensure our teachings are sustained for generations to come.

\section{Conclusion}

For too long, well-intentioned outsiders such as archeologists, anthropologists, sociologists ethnographers and others have produced irresponsible, inaccurate reports, texts and research papers on topics related to Indigenous peoples and cultures. It is essential that we, as Indigenous people, continue to de-colonize ourselves by reclaiming our histories, values, languages and traditions. The path towards self-determination means we will provide our own solutions to our own problems and bring to life the elements of our lives that have sustained us since time immemorial. Today, Indigenous people worldwide are taking necessary steps to initiate research reflecting their own needs and aspirations using Indigenous ways of knowing, being, seeing and doing to maintain strong people, communities, and Nations towards a self-determining future.

\section{References}

AIATSIS (Australian Institute of Aboriginal and Torres Strait Islander Studies). (2000). Guidelines for ethical research in Indigenous studies. Retrieved August 28, 2009 from http://www.aiatsis.gov.au/research/ docs/ethics.pdf.

Battiste, M. (Ed.). (2000). Reclaiming Indigenous voice and vision. Vancouver, BC: University of British Columbia Press.

Battiste, M., \& Henderson, J. (2000). Protecting Indigenous knowledge and heritage: A global challenge. Saskatoon, SK: Purich Publishing Ltd.

Beck, P. V., \& Walters, A. L. (1977). The sacred: Ways of knowledge, sources of life. Tsaile, AZ: Navajo Community College Press.

Callison, C. (1995). Appropriation of Aboriginal oral traditions. Paper written to satisfy requirements for Law 472: Trade in Cultural Property. Faculty of Law, The University of British Columbia.

Cape Breton University. (2010). Research principles and protocols Mi'kmaw ethics watch. Retrieved March 22, 2010 from http://mrc. cbu.ca/prinpro.html.

Carnoy, M. (1974). Education as cultural imperialism. New York: David McKay.

Deloria Jr. V. (1991). Commentary: Research, redskins and reality. American Indian Quarterly, 15, 457-459.

Gilchrest, L. (1997). Aboriginal communities and social science research: Voyeurism in transition. Native Social Work Journal, 1(1), 69-85.

Holmes, L. (2000). Heart knowledge, blood memory, and the voice of the land: Implications of research among Hawaiian Elders. In G. Dei, B. Hall, \& D. Rosenberg (Eds.), Indigenous knowledges in global contexts: Multiple readings of our world (pp. 37-53). Toronto, ON: University of Toronto Press.

Indian and Northern Affairs Canada. (1996). Report of the Royal Commission on Aboriginal Peoples. Retrieved March 18,2010 from http://www.collectionscanada.gc.ca/webarchives/20071115053257 http://www.ainc-inac.gc.ca/ch/rcap/sg/sgmm e.html. 


\section{Re-Conceptualizing Research: An Indigenous Perspective}

Little Bear, L. (2000). Jagged worldviews colliding. In M. Battiste (Ed.), Reclaiming Indigenous voice and vision (pp. 77-85). Vancouver, BC: University of British Columbia Press.

Menzies, C. (2004). Putting words into action: Negotiating collaborative research in Gitxaala. Canadian Journal of Native Education, 28(1\&2), $15-32$.

Ormiston, T. (2002). Aboriginal Child and Family Services: A First Nations Analysis of Delegated Services in BC. Unpublished 598 Management report, University of Victoria, Victoria, BC.

Perley, D. G. (1993). Aboriginal education in Canada as internal colonialism. Canadian Journal of Native Education, 19, 118-135.

Rigney, L.-I. (1999). Internationalization of an Indigenous anti-colonial cultural critique of research methodologies: A guide to Indigenist research methodology and its principles. WICAZO SA Review: Journal of Native American Studies, 14(2), 109-122.

Ross, R. (1996). Returning to the teachings: Exploring Aboriginal justice. Toronto, ON:Penguin Books.

Smith, L. T. (1999). Decolonizing methodologies: Research and Indigenous peoples. London: Zed Books.

Trask, H. K. (1999). From a Native daughter: Colonialism and sovereignty in Hawai'i. Honolulu: University of Hawaỉi Press.

Trigger, D., \& Williams, M. (1997). Anthropology's canon and Aboriginal knowledge in Australia: The politics of doing Indigenous studies in the 1990s. Paper prepared for the American Ethnological Society Conference, Seattle, March 6-9, 1997.

University of Victoria. (2003). Protocols and principles for conducting research in an Indigenous context. Retrieved March 22, 2010 from http://research. lakeheadu.ca/protocol.pdf.

Wax, M. L. (1991). The ethics of research in American Indian communities. American Indian Quarterly, 15(4), 431-456. 